\title{
Stevia rebaudiana Bertoni: health promoting properties and therapeutic applications
}

\author{
Katarzyna Marcinek ${ }^{1} \cdot$ Zbigniew Krejpcio $^{1}$
}

Received: 21 February 2015/Accepted: 15 June 2015/Published online: 12 July 2015

(c) The Author(s) 2015. This article is published with open access at Springerlink.com

\begin{abstract}
Stevia is a genus of approx. 200 species of herbs and shrubs from the family Astraceae. One of the representatives of the genus is sweetleaf Stevia rebaudiana, formerly called Eupatorium rebaudianum Bertoni (Yadav et al. in Can J Plant Sci 91:1-27, 2011). $S$. rebaudiana Bertoni has been known for many centuries by indigenous tribes of South America, who called it "kaa-hee" (sweet herb). South American Indians used stevia both as a sweetener and as a medicinal plant. Folk medicine of Paraguayan indigenous tribes recommends it particularly as a substance strengthening the heart, the circulatory system and regulating blood pressure. Sweetleaf is also used in liver disease, stomachache, gastric hyperacidity and as a mild agent stimulating the nervous system. It exhibits antibacterial, antifungal and anticaries properties. Nutritive and health-promoting properties of stevia are presently being investigated in many research centres. The aim of this paper is to present the health-promoting value of S. rebaudiana as stevia leaf powder, crude leaf extract or steviol glycosides (highly purified stevioside, rebaudioside $\mathrm{A}$ ).
\end{abstract}

Katarzyna Marcinek

katarzyna.marcinek1@gmail.com

1 Department of Human Nutrition and Hygiene, Poznań University of Life Sciences, Wojska Polskiego 31, 60-624 Poznan, Poland
Keywords Hypoglycemic effect . Hypotensive effect - Rebaudioside A - Safety . Stevia rebaudiana Bertoni - Stevioside . Therapeutic applications

\section{Health-promoting properties of stevia}

The energy value of stevia is approx. $2.7 \mathrm{kcal} / \mathrm{g}$ dry matter (Savita et al. 2004), which is comparable to other low-caloric commercially available intensive sweeteners. Stevia may substitute commonly used sucrose, thus reducing the consumption of simple sugars, which is advisable in the prevention of caries, obesity, type 2 diabetes and other civilisationrelated diseases. Steviol glycosides are not digested in the alimentary tract, they are broken down to steviol and glucose by the bacteria colonising the large intestine. Glucose released is not absorbed to the bloodstream, but metabolized by the intestinal flora. In turn, steviol is transformed to glucuronide in the liver and released in this form with urine and faeces (Atteh et al. 2011). Acceptable daily intake of steviol glycosides, expressed as steviol equivalents, was established at $4 \mathrm{mg} / \mathrm{kg}$ b.w. per day. However, most researchers are of the opinion that a daily intake of $5 \mathrm{mg} / \mathrm{kg}$ b.w. per day of steviol glycosides is safe and has no teratogenic or carcinogenic effects (Chatsudthipong and Muanprasat 2009; Awney et al. 2011). A study by Awney et al. (2011) conducted on young male rats showed that only a dose as high as $1500 \mathrm{mg} / \mathrm{kg}$ b.w. exhibits toxic action and has a negative effect on hematological and biochemical parameters of the blood and enzyme activity. 


\section{Hypotensive effect}

The hypotensive effect of stevioside consists in blocking the inflow of $\mathrm{Ca}^{2+}$ ions to vascular smooth muscle cells, which promotes vasodilation as well as reduces total peripheral resistance and volume of extracellular fluid as a result of increased diuresis and natriuresis (Bugaj et al. 2013). Savita et al. (2004) conducted studies on the effect of stevia leaf powder on blood glucose level and arterial pressure in six patients with type 2 diabetes and eight patients with arterial hypertension. The participants of the experiment consumed sweet snacks with an addition of stevia leaf powder at 0.5-1.0 g per $100 \mathrm{~g}$ final product for 30 days. At the same time, they were advised to slightly modify their diet. Stevia was found to have no effect on blood glucose level, blood pressure, insulin or the lipid profile (Savita et al. 2004). In contrast, the hypotensive effect of stevioside was observed in a study by Chan et al. (2000) conducted with the participation of 106 women aged 28-75 years suffering from hypertension (diastolic blood pressure 95-100 mm $\mathrm{Hg}$ ), who for 1 year were administered $0.25 \mathrm{~g}$ stevioside three times daily. As a result systolic and diastolic blood pressure of these women decreased already after 7 days by 14 and $14.3 \mathrm{~mm} \mathrm{Hg}$. The authors (Chan et al. 2000) stated that the administration of steviosides might be an alternative or adjunctive treatment in arterial hypertension. They also observed that oral administration of steviosides does not alter BMI values or biochemical parameters in blood. Arterial tension was also observed to decrease by approx. $7 \%$ in a study by Barriocanal et al. (2008) in a group of patients consuming stevioside in comparison to the control administered placebo. This effect was permanent and was maintained for up to 2 years. Moreover, the incidence rate of left ventricular hypertrophy was lower in the experimental group than in the control. The hypotensive effect was also shown in studies on dogs and rats administered $0.750 \mathrm{mg}$ steviol glycosides or placebo daily. Stevioside intervention caused a considerable reduction of diastolic and systolic blood pressure. Similar results were also reported in other studies (Hsieh et al. 2003; Lee et al. 2001; Liu et al. 2003). The hypotensive effect of steviosides obtained from Stevia rebaudiana Bertoni can be observed only in individuals suffering from arterial hypertension. This effect was not observed in healthy individuals (Geuns 2003). Apart from normalisation of blood pressure, the effect of stevia whole leaves powder on heart rate regulation was also reported
(Shivanna et al. 2013). It results from the analysis of literature data that only long-term (1-2 years) intake of stevia may effectively reduce arterial blood pressure (Ulbricht et al. 2010; Yang et al. 2004). No such effect was recorded in short-term studies lasting for 1-2 months. Maki et al. (2008) observed no effect of rebaudioside A intake at $1000 \mathrm{mg} / \mathrm{kg}$ b.w. on arterial blood pressure in patients with normal and low arterial pressure. Metaanalysis of the existing reports does not confirm significant hypotensive effects of stevia glycosides on systolic blood pressure vs. placebo, while appreciable lowering effects on diastolic blood pressure and blood glucose level have been observed (Onakpoya and Heneghan 2014).

\section{Hypoglycemic effect}

Stevia rebaudiana Bertoni has been used as a hypoglycemic substance for hundreds of years in Paraguayan and Brazilian medicine. In 1986, observations were conducted on 16 healthy individuals drinking aqueous extracts of $5 \mathrm{~g} S$. rebaudiana leaves or arabinose solution for 3 days at 6-h intervals. Glucose tolerance tests were conducted before and after intervention. An increased glucose tolerance was observed among the individuals administered stevia extracts (Curi et al. 1986). The hypoglycemic action of stevia glycosides was confirmed in a study by Gregersen et al. (2004) conducted with twelve participants (four women and eight men). The analyses were conducted on patients with at least a 4-year history of type 2 diabetes, who were supplemented daily with $1 \mathrm{~g}$ stevioside or $1 \mathrm{~g}$ maize starch added to a meal. A lesser increase in postprandial glycemia and the insulin index was observed in the group of individuals administered steviosides. Similar conclusions were presented by Taiwanese researchers, who investigated the effect of steviol glycosides on the metabolism of glucose and insulin in two groups of diabetic rats (Chen et al. 2005). In the first group, hyperglycemia was induced using Streptozotocin, while in the other group diabetes was induced by administering fructose (insulin-dependent diabetes). Stevioside intake resulted in a reduced insulin resistance in these animals and a simultaneous suppression of glucagon secretion. Stevioside is capable of reducing the amount of glucagon secreted, probably thanks to the increased mRNA expression of carnitine palmitoyltransferase, peroxisome proliferator-activated receptor alpha (PPAR-alpha) and stearoyl-CoA desaturase (Chen et al. 2005; Thomas 
and Glade 2002). A study by Jeppesen et al. (2003) conducted on GK rats (a non-obese Wistar substrain which develops type 2 diabetes mellitus early in life) showed that intake of $0.025 \mathrm{~g} / \mathrm{kg}$ b.w. stevioside has a hypoglycemic effect. This effect is ascribed to an increased secretion of insulin and induction of genes associated with glycolysis. Stevioside does not only turn out to be a substance exhibiting a hypoglycemic action, but a similar effect may also be ascribed to rebaudioside $\mathrm{A}$, which was confirmed by Danish researchers when investigating the effect of this compound on the release of insulin from pancreatic islets (Abudula et al. 2004). It was found that stimulation of insulin secretion is dependent simultaneously on the dose of stevioside and the presence of extracellular $\mathrm{Ca}^{2+}$ ions. Mohd-Radzman et al. (2013) observed that stevioside has direct effects on 3T3-L1 insulin sensitivity via increase glucose uptake and enhanced expression of proteins involved in insulin-signaling pathway. Increased insulin secretion is connected with the closure of ATP-dependent potassium channels, which results in the depolarisation of pancreatic beta cells and activation of $\mathrm{Ca}^{2+}$ channels. Saravanan et al. (2012) evaluated the effect of rebaudioside A on the activity of hepatic enzymes participating in carbohydrate metabolism in rats with induced diabetes. Those authors showed that rebaudioside A considerably reduces blood glucose concentration and exhibits a protective action towards the pancreas. The hypoglycemic action of rebaudioside $A$ and stevioside may be explained by similarities in their structure. Holvoet et al. (2014) observed that glycosides of stevia improve metabolism of glucose, fat catabolism, bile acids metabolism, storage and transport of lipids in the liver of insulin resistant obese mice.

\section{Anti-inflammatory and antimicrobial action}

Boonkaewwan et al. (2006) investigated anti-inflammatory and immunomodulatory effects of steviosides and their metabolites on THP-1 cells. It was found that stevioside significantly inhibits lipopolysaccharides which strongly enhance the generation of proinflammatory cytokines: IL-beta (interleukine-1 $\beta$ ) and TNF-alpha (tumor necrosis factor- $\alpha$ ) by macrophages and monocytes. Stevioside moderately stimulates the release of TNF- $\alpha$ and IL- $1 \beta$ in THP- 1 cells cultures with no addition of lipopolysaccharide (LPS) through interaction with the toll-like receptor 4 (TLR4), the key receptor for LPS of Gram-negative bacteria. This means that in case of infection stevioside prevents the development of undesirable effects of the inflammatory response. In healthy individuals, the activity of monocytes is improved. Mizushina et al. (2005) showed that isosteviol, as product by acid hydrolysis of the steviol glycoside, strongly inhibits DNA polymerase and topoisomerase II, in this way delaying the growth of three types of cancer cells. Yingkun et al. (2013) conducted experiments on male BALB/c mice, which were administered stevioside or dexamethasone $1 \mathrm{~h}$ before nasal instillation of lipopolysaccharide, causing acute lung injury. It was observed that stevioside limited the lipopolysaccharide-induced lung injury and inhibited the production of proinflammatory cytokines, expression of cyclooxygenase II, inducible NO synthase as well as phosphorylation of $\mathrm{I} \kappa \mathrm{B}$ alpha and NF- $\kappa \mathrm{B}$. Wang et al. (2014a) observed anti-inflammatory and anti-apoptotic effects of stevioside on mice in which mammary gland epithelium was infected with Staphylococcus aureus (MMECs). The same group of researchers reported that intraperitoneal injection of stevioside dose-dependently decreases expression of TNF- $\alpha$, IL-1 $\beta$ and IL-6 via inhibition of phosphorylation of protein $\mathrm{NF}-\kappa \mathrm{B}$ and MAPK signaling pathways, whereas their mRNA expression was not obviously changed (Wang et al. 2014b).

Diterpene glycosides contained in stevia have bacteri- and fungicidal properties, which may be used in the prevention of caries and colds as well as treatment of wounds, burns and ulcerations. The anti-caries effect of stevia glycosides was shown in a study by Brambilla et al. (2014) conducted on 20 volunteers, who at adequate time intervals rinsed their mouth for 1 min with three solutions containing $10 \%$ stevioside, rebaudioside and sucrose, respectively. It was observed that after rinsing with the sucrose solution the $\mathrm{pH}$ of plaque was much lower than in the case of stevia-derived solutions. Additionally it was shown that stevioside inhibits the development of Streptococcus mutans responsible for caries development (Brambilla et al. 2014). Gamboa and Chaves (2012) also investigated antibacterial activity of stevia against bacterial strains from the genera Lactobacillus and Streptococcus. Ajagannanavar et al. (2014) observed that alcoholic extracts of stevia exert higher antibacterial activity against Streptococcus mutans and Lactobacillus acidophilus in comparison to aqueous extracts. Siddique et al. (2014) showed the antimicrobial activity of extracts from $S$. rebaudiana leaves against various bacterial and fungal pathogens (excluding Bacillus cereus and Bacillus megaterium). Stevia extracts also exhibit antiviral activity and are potential antirotavirus inhibitors. 
According to Takahashi et al. (2001), substances contained in stevia inhibit replication of four human rotavirus serotypes in vitro. In a study by Shivanna et al. (2013) conducted on 80 Wistar rats an advantageous effect of stevia whole leaf powder was shown in alleviation of liver and kidney diseases as well as oxidative stress. The latest study by Deshmukh and Kedari (2014) showed that methanolic and ethanolic extracts of $S$. rebaudiana exhibit anticancer activity in relation to the Caco-2 cell line.

Recently anti-neoplastic properties of $S$. rebaudiana Bertoni compounds have been investigated by some researchers (Mann et al. 2014; Vaško et al. 2014; Khaybullin et al. 2014). Khaybullin et al. (2014) found that isosteviol derivatives possess cytotoxic activity on tumor cells derived from primary and metastatic cancer cells.

\section{Safety of application in foodstuffs}

Stevia rebaudiana Bertoni belongs to the Asteraceae (Compositae) family, like ragweed, goldenrod, chrysanthemum, echinacea, chamomile, lettuce, sunflower and chicory. Based on this common taxonomy, some popular media have issued food warnings alleging the potential for stevia allergy. A comprehensive literature review was conducted to identify all data available related to allergic responses following the consumption of stevia extracts or highly purified steviol glycosides. Hypersensitivity reactions to stevia in any form appear to be rare. Therefore, there is little substantiated scientific evidence to support warning statements to consumers about allergy to highly purified stevia extracts (Urban et al. 2015).

The primary objective of stevia use in food is to reduce its energy value by reducing the content of simple sugars in the product. For years, steviol glycosides have been used as sweeteners in many countries worldwide. In 2008, the Joint FAO/WHO Expert Committee on Food Additives (JECFA) concluded from the research results available that steviol glycosides obtained from $S$. rebaudiana are safe for human health and authorised their use in the USA. The European Food Safety Agency (EFSA) evaluated the safety of steviol glycosides obtained from leaves of $S$. rebaudiana Bertoni as sweeteners and established the acceptable daily intake (ADI) of steviol glycosides given as steviol equivalents at $4 \mathrm{mg} / \mathrm{kg}$ b.w. per day (EFSA 2010). This opinion was confirmed in November 2011 by the final decision of the European Commission accepting sweeteners derived from stevia for use in food. The Regulation of the European Commission no. 1131/2011 of 11 November 2011 presented maximum levels of steviol glycosides (E960) in food expressed as steviol equivalents in $\mathrm{mg} /$ $\mathrm{kg}$ product. Steviol equivalents are calculated based on conversion coefficients of steviol glycosides to steviol in the alimentary tract. These coefficients for rebaudioside $A$ and stevioside amount to 0.33 and 0.4, respectively (Carakostas et al. 2008).

\section{Conclusion}

Stevia rebaudiana Bertoni has an increasingly extensive range of applications worldwide not only as a sweetener, but also as a food additive reducing the energy value of food products. Despite numerous studies confirming health-promoting properties of stevia and its potential applications as an adjunctive substance in treatment of many chronic diseases, further research is required to determine interactions of stevia metabolites with food components and to corroborate the acceptable daily intake of this food additive.

Open Access This article is distributed under the terms of the Creative Commons Attribution 4.0 International License (http://creativecommons.org/licenses/by/4.0/), which permits unrestricted use, distribution, and reproduction in any medium, provided you give appropriate credit to the original author(s) and the source, provide a link to the Creative Commons license, and indicate if changes were made.

\section{References}

Abudula R, Jeppesen PB, Rolfsen SE, Xiao J, Hermansen K (2004) Rebaudioside A potently stimulates insulin secretion from isolated mouse islets: studies on the dose-, glucose-, and calcium-dependency. Metabolism 53(10):1378-1381

Ajagannanavar SL, Shamarao S, Battur H, Tikare S, Al-Kheraif AA, Al Sayed MS (2014) Effect of aqueous and alcoholic Stevia (Stevia rebaudiana) extracts against Streptococcus mutans and Lactobacillus acidophilus in comparison to chlorhexidine: an in vitro study. J Int Soc Prev Community Dent 4(2):116-121

Atteh J, Onagbesan O, Tona K, Buyse J, Decuypere E, Geuns J (2011) Potential use of Stevia rebaudiana in animal feeds. Arch Zootec 60:133-136

Awney HA, Massoud MI, El-Maghrabi S (2011) Long-term feeding effects of stevioside sweetener on some toxicological parameters of growing male rats. J Appl Toxicol 31(5):431-438

Barriocanal LA, Palacios M, Benitez G, Benitez S, Jimenez JT, Jimenez N, Rojas V (2008) Apparent lack of pharmacological effect of steviol glycosides used as sweeteners in humans. A pilot study of repeated exposures in some normotensive and hypotensive individuals and in type 1 and type 2 diabetics. Regul Toxicol Pharmacol 51(1):37-41 
Boonkaewwan C, Toskulkao C, Vongsakul M (2006) Antiinflammatory and immunomodulatory activities of stevioside and its metabolite steviol on THP-1 cells. J Agric Food Chem 54(3):785-789

Brambilla E, Cagetti MG, Ionescu A, Campus G, Lingström P (2014) An in vitro and in vivo comparison of the effect of Stevia rebaudiana extracts on different caries-related variables: a randomized controlled trial pilot study. Caries Res 48(1):19-23

Bugaj B, Leszczyńska T, Pysz M, Kopeć A, Pacholarz J, PyszIzdebska K (2013) Charakterystyka i właściwości prozdrowotne Stevia rebaudiana Bertoni. ŻYWNOŚć Nauka Technologia Jakość 3(88):27-38

Carakostas MC, Curry LL, Boileau AC, Brusick DJ (2008) Overview: the history, technical function and safety of rebaudioside $\mathrm{A}$, a naturally occurring steviol glycoside, for use in food and beverages. Food Chem Toxicol 46:1-10

Chan P, Tomlinson B, Chen YJ, Liu JC, Hsieh MH, Cheng JT (2000) A double blind placebo-controlled study of the effectiveness and tolerability of oral stevioside in human hypertension. Br J Clin Pharmacol 50(3):215-220

Chatsudthipong V, Muanprasat $\mathrm{CH}$ (2009) Stevioside and related compounds: therapeutic benefits beyond sweetness. Pharmacol Ther 121:41-54

Chen TH, Chen SC, Chan P, Chu YL, Yang HY, Cheng JT (2005) Mechanism of the hypoglycemic effect of stevioside, a glycoside of Stevia rebaudiana. Planta Med 71(2):108-113

Curi R, Alvarez M, Bazotte RB, Botion LM, Godoy JL, Bracht A (1986) Effect of Stevia rebaudiana on glucose tolerance in normal adult humans. Braz J Med Biol Res 19(6):771

Deshmukh SR, Kedari VR (2014) Isolation, purification and characterization of sweetners from Stevia rebaudiana (Bertoni) for their anticancerous activity against colon cancer. WJPPS 3(5):1394-1410

European Food Safety Authority (EFSA) (2010) Scientific opinion on the safety of steviol glycosides for the proposed uses as a food additive. EFSA J 8(4):1537

Gamboa F, Chaves M (2012) Antimicrobial potential of extracts from Stevia rebaudiana leaves against bacteria of importance in dental caries. Acta Odontol Latinoam 25(2):171-175

Geuns J (2003) Stevioside. Phytochemistry 63:913-921

Gregersen S, Jeppesen PB, Holst JJ, Hermansen K (2004) Antihyperglycemic effects of stevioside in type 2 diabetic subjects. Metabolism 53:73-76

Holvoet P, Rull A, García-Heredia A, López-Sanromà S, Geeraert B, Joven J, Camps J (2014) Stevia-derived compounds attenuate the toxic effects of ectopic lipid accumulation in the liver of obese mice: a transcriptomic and metabolomic study. Food Chem Toxicol 29:22-33

Hsieh MH, Chan P, Sue YM, Liu JC, Liang TH, Huang TY, Tomlinson B, Chow MS, Kao PF, Chen YJ (2003) Efficacy and tolerability of oral stevioside in patients with mild essential hypertension: a two-year, randomized, placebocontrolled study. Clin Ther 25:2797-2808

Jeppesen PB, Gregersen S, Rolfsen SED, Jepsen M, Colombo M, Agger A, Xiao J, Kruhøffer M, Ørntoft T, Hermansen K (2003) Antihyperglycemic and blood pressure-reducing effects of stevioside in the diabetic Goto-Kakizaki rat. Metabolism 52:372-378

Khaybullin RN, Zhang M, Fu J, Liang X, Li T, Katritzky AR, Okunieff P, Qi X (2014) Design and synthesis of isosteviol triazole conjugates for cancer therapy. Molecules 19(11):18676-18689

Lee CN, Wong KL, Liu JC, Chen YJ, Cheng JT, Chan P (2001) Inhibitory effect of stevioside on calcium influx to produce antihypertension. Planta Med 67:796-799
Liu JC, Kao PK, Chan P, Hsu YH, Hou CC, Lien GS, Hsieh MH, Chen YJ, Cheng JT (2003) Mechanism of the antihypertensive effect of stevioside in anesthetized dogs. Pharmacology 67:14-20

Maki KC, Curry LL, Carakostas MC, Tarka SM, Reeves MS, Farmer MV, Mckenney JM, Toth PD, Schwartz SL, Lubin BC, Dicklin MR, Boileau AC, Bisognano JD (2008) The hemodynamic effects of rebaudioside A in healthy adults with normal and low-normal blood pressure. Food Chem Toxicol 46:40-46

Mann TS, Agnihotri VK, Kumar D, Pal PK, Koundal R, Kumar A, Padwad YS (2014) In vitro cytotoxic activity guided essential oil composition of flowering twigs of Stevia rebaudiana. Nat Prod Commun 9(5):715-718

Mizushina Y, Akihisa T, Ukiya M, Hamasaki Y, Murakami-Nakai C, Kuriyama I, Takeuchi T, Sugawara F, Yoshida H (2005) Structural analysis of isosteviol and related compounds as DNA polymerase and DNA topoisomerase inhibitors. Life Sci 77(17):2127-2140

Mohd-Radzman NH, Ismail WIW, Jaapar SS, Adam Z, Adam A (2013) Stevioside from Stevia rebaudiana Bertoni increases insulin sensitivity in 3T3-L1 adipocytes. Evid Based Complement Alternat 1-8. doi:10.1155/2013/938081

Onakpoya IJ, Heneghan CJ (2014) Effect of the natural sweetener, steviol glycoside, on cardiovascular risk factors: a systematic review and meta-analysis of randomised clinical trials. Eur J Prev Cardiol [Epub ahead of print]

Saravanan R, Vengatash Babu K, Ramachandran V (2012) Effect of Rebaudioside A, a diterpenoid on glucose homeostasis in STZ-induced diabetic rats. J Physiol Biochem 68(3):421-431

Savita SM, Sheela K, Sunanda S, Shankar AG, Ramakrishna P, Sakey S (2004) Health Implications of Stevia rebaudiana. J Hum Ecol 15(3):191-194

Shivanna N, Naika M, Khanum F, Kaul VK (2013) Antioxidant, anti-diabetic and renal protective properties of Stevia rebaudiana. J Diabetes Complicat 27(2):103-113

Siddique AB, Rahman SMM, Hossain MA, Rashid MA (2014) Phytochemical screening and comparative antimicrobial potential of different extracts of Stevia rebaudiana Bertoni leaves. Asian Pac J Trop Dis 4(4):275-280

Takahashi K, Matsuda M, Ohashi K, Taniguchi K, Nakagomi O, Abe Y, Mori S, Sato N, Okutani K, Shigeta S (2001) Analysis of anti-rotavirus activity of extract from Stevia rebaudiana. Antiviral Res 49(1):15-24

Thomas JE, Glade MJ (2002) Stevia: it's not just about calories. Open Obes J 2:101-109

Ulbricht C, Isaac R, Milkin T, Poole EA, Rusie E, Grimes Serrano JM, Weissner W, Windsor RC, Woods J (2010) An evidencebased systematic review of stevia by the Natural Standard Research Collaboration. Cardiovasc Hematol Agents Med Chem 8(2):113-127

Urban JD, Carakostas MC, Taylor SL (2015) Steviol glycoside safety: are highly purified steviol glycoside sweeteners food allergens? Food Chem Toxicol 75:71-78

Vaško L, Vašková J, Fejerčáková A, Mojžišová G, Poráčová J (2014) Comparison of some antioxidant properties of plant extracts from Origanum vulgare, Salvia officinalis, Eleutherococcus senticosus and Stevia rebaudiana. Vitro Cell Dev Biol Anim 50(7):614-622

Wang T, Song X, Zhang Z, Guo M, Jiang H, Wang W, Cao Y, Zhu L, Zhang N (2014a) Stevioside inhibits inflammation and apoptosis by regulating TLR2 and TLR2-related proteins in S. aureus-infected mouse mammary epithelial cells. Int Immunopharmacol 22(1):192-199 
Wang T, Guo M, Song X, Zhang Z, Jiang H, Wang W, Fu Y, Cao Y, Zhu L, Zhang N (2014b) Stevioside plays an antiinflammatory role by regulating the NF- $\kappa$ B and MAPK pathways in $S$. aureus-infected mouse mammary glands. Inflammation 37(5):1837-1846

Yadav AK, Singh S, Dhyani D, Ahuja PS (2011) A review on the improvement of stevia [Stevia rebaudiana (Bertoni)]. Can J Plant Sci 91:1-27
Yang HY, Chan P, Yang HY, Hsu FL, Liu IM, Cheng YW, Cheng JT (2004) Isosteviol acts on potassium channels to relax isolated aortic strips of Wistar rat. Life Sci 74:2379-2387

Yingkun N, Zhenyu W, Jing L, Xiuyun L, Huimin Y (2013) Stevioside protects LPS-induced acute lung injury in mice. Inflammation 36(1):242-250 